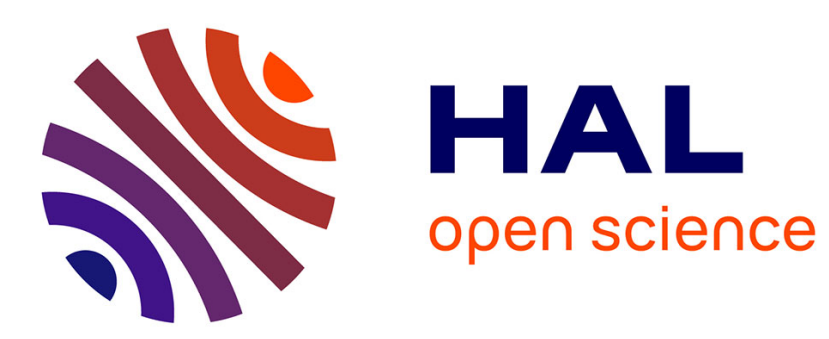

\title{
Punishing tax offenders in France and Great Britain: two criminal policies
}

\author{
Alexis Spire, Katia Weidenfeld
}

\section{To cite this version:}

Alexis Spire, Katia Weidenfeld. Punishing tax offenders in France and Great Britain: two criminal policies. Journal of Financial Crime, 2017. hal-02273409

\section{HAL Id: hal-02273409 \\ https://hal.science/hal-02273409}

Submitted on 28 Aug 2019

HAL is a multi-disciplinary open access archive for the deposit and dissemination of scientific research documents, whether they are published or not. The documents may come from teaching and research institutions in France or abroad, or from public or private research centers.
L'archive ouverte pluridisciplinaire HAL, est destinée au dépôt et à la diffusion de documents scientifiques de niveau recherche, publiés ou non, émanant des établissements d'enseignement et de recherche français ou étrangers, des laboratoires publics ou privés. 


\title{
Punishing tax offenders in France and Great Britain: two criminal policies
}

\author{
Alexis Spire (CNRS -PSL) \\ Katia Weidenfeld (Ecole Nationale des Chartes -PSL)
}

\begin{abstract}
Since roughly 2008-2009, the governments in France and in Britain have encouraged more rigorous penalization of tax fraud. In this article, we compare the implementation of these policies in the two countries on the basis of qualitative and quantitative data. Whilst publicly calling for harsh punishment against tax dodgers, in practice both governments tend to seek a balance between the growing demand for tax equality and the belief that the State should not intervene in the economic realm. The result is a different approach on either side of the Channel: whereas the British institutions support an "exemplary punitive" system, French regulatory system favours a "quasi-administrative" treatment.
\end{abstract}

\section{Keywords}

Tax fraud, white-collar crime, penalization, France, Great Britain

\section{Introduction}

Tax fraud is a white-collar crime that has long been subjected to the indifference of courts and criminologists (Sutherland 1949; Levi 1981). With rare exceptions such as the pioneering 
research of Schwartz and Orleans (1967), it is only since the end of the 1970s that this issue has truly aroused the interest of researchers.

For the most part, the literature has focused on the effects of criminalizing tax fraud in terms of regulatory enforcement. The usual objective is to understand how taxpayer compliance results from three mechanisms of inhibition: formal sanction (the penalty stipulated by law), informal sanction (social stigma), and internalization of the legal norm (awareness of a breach in the social contract). Many theoretical and empirical studies have sought the causes of fraud (for a synthesis, see Roth and Scholz 1989, 71) and have attempted to determine which tool might have the greatest deterrent effect (Klepper and Nagin 1987; Braithwaite 1989, 2007; Murphy 2008; for a critique, see Levi 2010).

Fewer studies have been conducted with the intent of showing how institutions tend to treat this type of white-collar crime, which is the challenge we take up here. In France, Lascoumes (1983) highlighted the numerous layers of administrative filters applied before any criminal prosecutions are actually launched when shortfalls in tax payments have been detected. In Great Britain, Dee Cook (1989) demonstrated that the treatment of tax fraud was much more conciliatory than the management of social fraud. To complete this picture, McBarnet (1991) showed that in addition to being treated more generously by institutions, the taxpayers (who are more well off in terms of financial and social resources than the average offender) have developed active strategies to avoid that their actions be labelled as criminal. This ability to "manage the stigma" has been facilitated by the adhesion of most Western tax authorities to the service-oriented approach. Considering that appeals to civic-mindedness and inducements to cooperation are more effective in gaining tax compliance than threats of punishment, they have 
developed tools for cooperation with taxpayers, retaining the assumption that non-compliance falls primarily under the category of avoidance (not under the category of evasion).

Nevertheless, at the end of the first decade of the twenty-first century, the revelation of major instances of tax evasion through secret Luxembourg based bank accounts acted as a trigger in France and in Great Britain. Tax fraud control and punishment have become politicized and the subject of public debate. In France and in Great Britain, the controversy implies two divergent strategies for punishing tax crime, revealing two kinds of penal rationalities. In a key contribution to the literature on punishment, Garland distinguished two contrasting visions in contemporary criminal justice: "the passionate, morally-toned desire to punish and the administrative, rationalistic normalizing concern to manage" (Garland 1990, 180). Reviewing the work of Garland, Braithwaite has argued that this demonstration was focused on punitive regulation of the poor and had no resonance in business regulation (Braithwaite 2003, 14).

In this article, we want to use Garland's distinction between the two strategies of punishment as a starting point to understand the differences between the French and the British manner in revitalizing the penal tools against tax fraud. Our intent is not to determine which model is most effective in persuading taxpayers to comply with the law but to emphasize that, while the two criminal policies in Britain and in France take their roots in a same awareness of tax fraud, in practice they set different objectives for criminal punishment.

On both sides of the Channel, apparent efforts have been made to change the way of dealing with tax fraud. Successive governments at Downing Street have encouraged the tax department to increase the number of criminal prosecutions of tax evaders: the decision to empower the Crown Prosecution Service to conduct these prosecutions symbolizes the intention to treat this offence as a real crime. Almost simultaneously in France, a new legal procedure was enacted for 
the repression of tax fraud. However, this commitment to promote harsher treatment of tax offences is severely hampered by the unwavering belief that tax fraud requires mainly a civil response.

In the first part of the study, we describe the recent evolution of the machinery for screening tax related wrongdoings in France and in the UK. Despite their resolute declarations, institutions in both countries remain trapped by a tolerance of tax evasion that is embedded in practice and in social representation. Although various citizen organizations espouse a claim for fiscal justice, political, economic and social institutions persist in the idea that the criminal law must be kept separate from the "free market" (Harcourt 2011).

In the second part, we analyse both these systems of regulation as two strategies of punishment. In France, due to both the selection mechanisms at the source and the punishments meted out, the criminalization of tax fraud assumes a quasi-administrative function, namely to allow the taxing authority to recover its tax claim. In the United Kingdom, large corporations continue to be widely protected from prosecution, while categories of individual tax evaders are targeted and severely sentenced, illustrating an exemplary punitive approach.

\section{Data and Methods}

The study done in France includes a first qualitative component that consists in a series of interviews conducted between 2012 and 2014 with various representatives of law enforcement agencies: we met with eighteen agents of the tax administration (occupying different positions within the tax authority), six prosecutors, six judges, the representatives of two police services dealing with tax fraud, three barristers of the two law firms that represent the Treasury before the Courts. The qualitative component has been augmented by the observation of hearings (around hundred cases). This investigation took place during the implementation of reforms (as described 
below), allowing us to observe the traditional way of dealing with tax offences as well as the new method. The study also relies on public statistics, which we have supplemented by the creation of a database compiled from 593 (unbiased) cases of tax fraud submitted to the judiciary and resulting in a judgement or decision rendered in 2011. This sample enabled us to determine more precisely the social characteristics of taxpayers involved (namely their age, nationality, profession, criminal background), the types fraud case prosecuted (namely the nature of the tax and consistency of the fraudulent schemes) and the penalties sanctioning them.

In order to develop a comparison with Great Britain, interviews were conducted with different participants in the fight against tax fraud: we met with ten agents of the Criminal Tax Investigations of Her Majesty's Revenue and Customs (HMRC), three representatives of the Crown Prosecution Service (CPS) and three barristers representing it, and we observed four trials for tax fraud (in addition to those reported in the press). The published statistical information was supplemented using Freedom of Information Requests; but unfortunately, no data about the social characteristics of the prosecuted taxpayers were communicated to us.

\section{Defining Deviancy Down}

Although in "Defining Deviancy Down", Moynihan (1993) described a process that was fully operative in matters of tax fraud for decades, policing strategy has now been adjusted upward. In France, two new laws were adopted in December of 2013, following the "Cahuzac Affair" (from the name of a French Finance minister indicted for the diversion of 600,000 euros to an undeclared Swiss bank account). In Great Britain, this change in strategy was reflected in the January 2013 speech by the director of the Crown Prosecution Service who announced that "the criminal justice response to tax evasion is being ramped up". However, despite these official 
statements claiming that tax fraud is currently handled as a conventional crime, its true regulation is far from being imbued with "zero tolerance".

\section{A funnel-like screening machine}

As in the past, and as is the case for all white-collar crime, tax evasion is very weakly criminalized (Murphy, 2005). In France, of the 50,000 in-depth verifications carried out annually, inspectors consider roughly 16,000 to be deliberate frauds. All of them could be criminally prosecuted, but the administration generally applies civil penalties (fines). Criminal charges are brought by the tax authority against only about thousand taxpayers a year. In the United Kingdom, the selection is even more restrictive: although the number has risen since the end of the first decade of the 2000s, prosecutions for tax evasion have remained slightly below 900 for the year 2013-2014.

As for other white-collar offences such as securities fraud (see Eitle 2000), this Malthusianism is the result of a range of institutions that act as filters before actual prosecution (see Figures 1 and 2). In France, the law gives the central role in screening tax-related wrongdoings to the tax agents: no prosecution against tax fraud can take place without their initiative. The tax inspector and his brigade chief make proposals to the departmental management, which selects certain cases and then submits them at the central level. After that, a "Commission of Tax Offences", composed of high-ranking magistrates, gives its authorization according to certain internal criteria, such as the amount of the fraud (generally no prosecution is allowed when the amount at stake is below $€ 100,000$ ), or on humanitarian grounds (permission to prosecute is, for instance, often denied when the defendant is sick or too old). The complaint is then forwarded to the public prosecutor (the prosecuting authority being embedded in the judicial institution). Theoretically, the prosecutor can refuse to prosecute some offenders, but in practice, 
he rarely exercises his power of selection for tax offences. The decision to proceed with a criminal investigation is taken at this stage.

In the United Kingdom, the tax authority does not have a legal monopoly on actions to be taken against tax evaders. However, in reality the great majority of criminal cases originate from Her Majesty's Revenue and Customs (HMRC) after a range of internal filters has led to the decision to investigate criminally. However, the Crown Prosecution Service -whose resources are constantly shrinking- is more active than the French public prosecutor's office in the selection of offences to be prosecuted: it rejects approximately $15 \%$ of the files coming to it from the HMRC.

In practice, despite these institutional differences, the choice to prosecute criminally one tax evader rather than another remains mostly with the tax authority both in France and in Great Britain. On both sides of the Channel, this decision-making process tends to orient the bulk of prosecutions toward taxpayers who, even after being alerted to the suspicions directed at them, refuse all "co-operation" with the tax authority.

\section{How the rich usually escape prosecution}

In France, as in Great Britain, the tax authority only adopts a penal approach in a tiny number of cases, a policy that is consistent with a secular differential treatment of fiscal illegalities (Foucault 1979), but the targets are not the same on either side of the Channel.

The philosophy promoted in the British policy of the "Disclosure Facilities", used by HMRC since the end of the first decade of the 2000s, is to guaranty an amnesty to those who agree to reveal voluntarily their tax evasion, and conversely, to prosecute almost systematically those who refuse to obey the law (when evidence is found). The taxpayer's ability to avoid being 
labelled a criminal by means of his own behaviour has thus been institutionalized (McBarnet 1991).

Nevertheless, HMRC has discretionary power to exclude certain offenders from this amnesty mechanism, notably in consideration of the exemplary value that could arise from their prosecution. Indeed, the British tax authority specifically targets certain professions, especially legal professionals. Relative to theses professionals, the declared policy is to prosecute when fraud has been demonstrated, often denying them the opportunity for amnesty even if the amount in question is relatively limited. Some lawyers have thus become the object of legal inquiry, not only for their own frauds, but also for those they had counselled their clients to commit. This was the case, for example, of a tax expert regarding the sale of fraudulent arrangements for tax credits to wealthy clients. ${ }^{1}$

In France, the ability of taxpayers to choose whether or not to avoid criminal prosecution by agreeing to communicate with the tax authority is less clearly defined. Yet in practice, the tax agents' main objective being to ensure the flow of money into the coffers of State in the short term, they display a solid commitment to cooperation with taxpayers and have a strong incentive to allow a transaction, whatever the characteristics of the offender may be. This behaviour implies a differentiated approach to tax illegalities that benefits the offenders who have the social and financial capacity to proceed with the payment of their debt. Taxpayers of the upper class do not benefit from a complete immunity, but they are more often subjected to administrative and civil sanctions than to criminal prosecution.

In our sample of 593 judgements, no criminal prosecutions were initiated by the tax department responsible for the largest corporations, although more than a third of them did receive a notification of tax adjustment (Court of auditors 2012). The largest businesses are not 
the only ones that almost completely escape prosecution. In France, the best endowed taxpayers, whether in social or economic capital, are also largely exempt. The department that deals with them -with a portfolio that is significantly larger than that of its British counterpart ${ }^{2}-$ is $_{\text {the }}$ source of less than $2 \%$ of criminal complaints for tax fraud. Members of the liberal professions who evade taxes are also very well protected in France against any prosecution. In our sample of judgements, lawyers, accountants, architects and doctors represent less than $6 \%$ of the people prosecuted. In addition, very little attention is given to the professionals who facilitate the fraud. There has been but one conviction of a lawyer who had organized tax frauds.

Moreover, the patrimonial taxes, involving rights of succession or the solidarity tax on wealth, are almost never prosecuted. Thus, the cases of tax evasion that are prosecuted by the tribunals are mainly committed in the context of an activity performed for, or with the help of, an organization. The actions committed by people with high status, when unrelated to their occupation or organization, only very exceptionally come before judges.

The reasons for this weak criminalization of wealthy white-collar tax evaders and large companies are somewhat similar. On the one hand, persons possessing what are known as "great fortunes", who are surrounded by lawyers and have sufficient means, very freely discuss and negotiate issues with the tax authorities. In addition, the apparent complexity of tax laws puts a premium on the skill of the legal professionals in making their frauds look like errors (Mann 1985). Large corporations and rich people are indeed able to scramble the boundaries between what is legal and what is illegal (Nagels 2013). As a consequence, even when they are challenged on the civil field, their practice of "creative compliance" (McBarnet 2013) enables them to escape criminal prosecution. 
On the other hand, businesses, the largest in particular, enjoy excellent reputations because of the jobs they create and the consumer goods they offer. This situation constitutes an obstacle to criminal prosecution that could threaten their survival (Friedrich 2009). Consideration of public views also affects the proceedings against well-off individuals: tax agents are reluctant to prosecute evasion of patrimonial taxes, which carry less social legitimacy than other tax levies (Beckert 2007). Moreover, the investigatory powers conferred on the agents of the French tax administration who deal with the control over these taxes are even weaker than those granted to their counterparts dealing with VAT or corporation tax.

Since 2008, the French tax authority has encouraged its inspectors to treat "high profile" cases, as well as inheritance-related tax frauds, with criminal prosecution. A new investigatory team (the "police fiscal") ) has been created to address the issue of large-scale tax frauds involving wealthy people. Yet this policy, which deviates from many administrative patterns as well as from the dominant theoretical conception regarding white-collar crime, has led to limited results. Even if the frauds investigated by the new "police fiscal" has often entailed a patrimonial aspect, it was set aside - at least in the cases that have already led to public hearings. Inheritance taxes are almost never the subject of criminal prosecution.

The intention displayed by high-ranking French officials to target increasingly high profile taxpayers thus clashes with a profitability objective, which has systematically dominated the desire for criminal sanctions. In fact, the inspectors who specialize in the control of assets tend to believe that if the taxpayer agrees to pay back at least part of what is owed, a criminal prosecution then becomes unnecessary. The consequences for a group of taxpayers who possessed undeclared HSBC Swiss bank accounts offer a clear illustration: in France, all those who had participated in a process of regularization within the two or three years following the 
communication also avoided criminalization. This phenomenon was even more significant in Great Britain, where only one such taxpayer was in fact prosecuted.

In both countries since 2013-2014, the public's concern with the impunity of big business has risen. Some judges in France have taken it upon themselves to criminalize tax fraud schemes marketed by banks. However, the mechanisms described above that protect large businesses are only slightly undermined, and so-called "long-firm frauds"4 continue not to be thought of as a signal crime (Levi 1981): until now the only criminal prosecutions against large companies have been in the discredited banking sector and were essentially directed against foreign companies (namely the Swiss branch of HSBC, the Swiss banks UBS AG and Reyl and Co).

\section{"Blue collars", the courts' regular clients}

In both countries, the limiting of prosecution to taxpayers who refuse dialog and negotiation with the tax authority results in the prominence, amongst the frauds prosecuted, of "blue collars" who do not belong to the Power Elite (Mills 1963). The wrongdoings of these individuals are the courts' regulars cases since they are not technically complex and are easy to prove.

In close to one third of the cases in France, what is involved is a simple lack of reporting income (Voies et Moyens 2014). It is the essence of the offences attributed to the managers of building and civil engineering companies, which represent one quarter of French tax prosecutions. Most of these entrepreneurs do not answer letters from the tax authorities, do not produce any kind of accounts when required, and are, moreover, often judged in absentia. Our database reveals an over-representation of foreigners among these entrepreneurs. Forty-six percent of construction-related entrepreneurs criminally prosecuted for tax evasion are foreign nationals, and two-thirds were born outside France, while people living in France but born outside the country, represent only $11.5 \%$ of the population. In addition, one should note more 
generally the strong over-representation of foreigners among those prosecuted for tax evasion in France. Nearly one quarter of the people accused are not French, while foreigners in France represent only $6 \%$ of the total population. The over-representation of foreigners in the prosecution of tax evasion (25\% of the defendants) is much higher than for crime in general (around 12\%), as well as for economic and financial offences (around 14\%) according to the National Criminal Record, 2010-2013. The Turks seem to be the taxpayers who are most often singled out: in our sample, they alone are targeted by $10 \%$ of the prosecutions, while representing only $0.3 \%$ of the population of France. Such statistical differences raise the issue of possible discrimination by the services responsible for prosecuting tax fraud. In practice, such discrimination is very difficult to prove because the criterion of nationality cannot be considered independently from the behaviour of the taxpayers with respect to tax and the auditors' demands. As in other illegal practices (Heyman 1999), a significant proportion of the over-penalization of foreigners who have evaded taxes is explained by the nature and circumstances of the offences: for example, the Turks who are accused are very often managers (real or merely in name) of small construction companies that do not file tax returns and do not respond to any requests from the tax authority.

In France, the over-representation of building contractors and foreigners indicted for tax fraud creates a truncated image of crime which seems to emanate more from the "blue collars" than from the "white collars". This selection bias is amplified by the frequent presence among those prosecuted of people who act as front men. The judges we interviewed complained of often having to deal with defendants who had been approached to open an account in the name of a company and sign some documents in exchange for some small advantage or profit. In our sample of judgements, these cases represent $10 \%$ of those prosecuted. This form of sub- 
contracted illegality, very common in the construction industry (Heber 2009; Chauvin and Jounin 2010), is also very widely used to conceal tax fraud. The French tax authorities, whose powers of investigation are very limited, often do restrict their investigations to these visible suspects who are easy to prosecute, even though they often disappear when the trial begins, and even if their real liability is limited. Such is the case for instance of the Colombian house painter who dissimulated almost $€ 1$ billion, acting on behalf of bigger companies; he was convicted and sentenced, but the general contractors who hired him were not investigated. ${ }^{5}$

In Great Britain, the criminal investigators of HMRC surveyed claimed to prefer to use these "straw men" as witnesses against the real organizers of the fraud. Nevertheless, in this country too, small scale fraudsters are a significant proportion of the cases brought before the criminal courts. As a consequence of the "Comprehensive Spending Review, 2010", the increase in the resources dedicated to criminal investigations would have permitted the detection of a vast range of frauds, including not just complex tax schemes sold by unscrupulous tax advisors but also less sophisticated tax evasions of narrower scope (HMIC 2013). The agents of HM Revenue and Customs whom we interviewed claim to spend at least half of their time on simple cases relating to taxpayers who basically fail to declare their taxes or their revenue. However, the objective proclaimed by the units that specialize in the control of fraud-rich environments -such as restaurants, fast-food outlets, automobile-related businesses, real estate, security companies, concierges in London- is to show toughness. Thus, the cases they present to the "Serious Evasion Team" have, according to the agents interviewed, a strong likelihood of being selected for criminal proceedings. Such was the case, for example, for two restaurateurs of dual English and Bangladeshi nationality, who were prosecuted for not having filed any tax declarations for the preceding five years. ${ }^{6}$ The amnesty campaigns aimed at plumbers or members of the building 
trades had similar effects: those who did not embrace the opportunity to regularize their affairs were targeted for criminal prosecution. At the end of the first campaign, five criminal prosecutions were initiated for tax evasion because of the failure to declare income ranging from $£ 40,000$ to $£ 91,000$. Moreover, the agents of HMRC chose cases that had high a probability of leading expeditiously to a guilty plea (which occurs in about $60 \%$ of cases according to the agents interviewed) and would avoid an expensive trial. This concern for efficiency often leads to the penalization of relatively poor taxpayers.

Thus, in France as well as in Great Britain, the defendants who must appear before a judge for tax evasion are carefully filtered and represent only a small proportion of taxpayers who have deliberately evaded taxes. While institutional modalities for filtering defendants are different on the two sides of the Channel, the two countries practice, each in their own way, a differential administration of tax illegalities: the managers of small companies often appear in court while the directors of large enterprises come much more rarely before a criminal judge. This selection may be thought of as a form of penal pragmatism: in France as in Britain, the policy aims at maintaining a balance between the respect for the "free market" (which implies the prosecution of only a few schemes as fraud) and the public demand for repression of tax evasion (which requires the criminalization of all such cases). However, the outcome of the criminal trials are very different from one country to the other.

\section{Two penal strategies in the repression of tax offences}

In France, as in Great Britain, the agents who decide which tax evaders to prosecute will target cases where the evidence is strongest, which is why the rate of conviction is around $90 \%$. In both countries, the maximum penalties that can be imposed are relatively high: ten years for a large number of offences in the United Kingdom and five to seven years in France. Yet, despite these 
commonalities, the outcomes of the prosecution are very different in each country. In France, the judges try to avoid any stigmatization: the criminal conviction is above all aiming to give the tax authorities a new tool for the recovery of defrauded taxes. By contrast, in Great Britain the sentences continue to give prominence to visible punishment with the intent of casting shame upon the taxpayer in an exemplary punitive manner.

\section{Imprisonment}

In France, despite the mild increase in the recourse to such punishment since 2010, imprisonment is imposed in only $10 \%$ of convictions for tax fraud (Voies et Moyens 2014). A logistic regression was run to examine the impact of the variables extracted from our sample of 593 judgments on the likelihood of rendering a court order for custody (Table 1). The prison sentence is not significantly correlated to the age, nationality or sector of activity of the accused. Aside from the variable "gender" (Steffensmeier and Allan 1996), the only significant statistical determinant is the existence of previous court convictions.

\section{$\underline{\text { Table 1. Determining factors in prison-sentence verdicts }}$}

\begin{tabular}{|c|c|c|}
\hline Variables & Modalities & Odds ratio \\
\hline Gender & $\begin{array}{l}\text { Man } \\
\text { Woman }\end{array}$ & $\begin{array}{l}1 \\
0.3 *\end{array}$ \\
\hline Criminal record & $\begin{array}{l}\text { No criminal record } \\
\text { Criminal record }\end{array}$ & $\begin{array}{l}1 \\
24.3 * * *\end{array}$ \\
\hline Nationality & $\begin{array}{l}\text { French } \\
\text { Foreigner }\end{array}$ & $\begin{array}{l}1 \\
\text { Non significant }\end{array}$ \\
\hline Country of birth & $\begin{array}{l}\text { France } \\
\text { Abroad }\end{array}$ & $\begin{array}{l}1 \\
\text { Non significant }\end{array}$ \\
\hline Economic sector & $\begin{array}{l}\text { Other than construction } \\
\text { Construction }\end{array}$ & $\begin{array}{l}1 \\
\text { Non significant }\end{array}$ \\
\hline Year of birth & & Non significant \\
\hline
\end{tabular}

*** Significant at the $1 \%$ level; * significant at the $10 \%$ level.

Interpretation: the risk of being sentenced to jail for a female accused is three times lower than for a male accused with the same characteristics concerning his criminal record, his nationality, his country of birth, his year of birth and the economic sector of his occupation. 
The few cases in which a tax offender with no criminal record was sentenced to a term of imprisonment were of two types: either there was a connection between the tax fraud and some other conventional offence (especially trafficking in weapons or drugs), or the taxpayer brazenly refused to make amends in court. Even in such cases, the sentences passed by the court were short prison terms: (almost) never more than two years. Below this limit, the punishment is "convertible", which is to say that a convicted person who provides sufficient guarantees of social integration can ask to serve his sentence without incarceration (for example, under electronic surveillance or simply by paying a penalty).

In $80 \%$ of convictions for tax fraud, the sentence passed was a suspended term of imprisonment for an average length of nine months (Voies et Moyens 2014). Introduced into French penal law at the end of the nineteenth century, the suspended sentence was intended to play a warning role to prevent recidivism: it is revoked if a new conviction occurs within a period of five years. However, in relation to tax fraud, this function is completely illusory due to the length of time preceding court procedures: judgements are pronounced at least five years after the fact. Thus, the likelihood of a recidivist act revoking the suspended sentence is weak.

The judges we interviewed justify the absence of prison sentences in two ways. On one hand, they note the strong social integration of tax offenders and are reluctant to remove from society people who are perceived as having a productive activity (in their work, if not as employers). Hence, they share the idea that the function of incarceration in contemporary society is more to regulate poverty (Wacquant 2009) than to punish crime. The argument of the prison overpopulation is very powerful concerning these offenders who do not visibly threaten public order. On the other hand, the judges explain the frequent recourse to suspended sentences by the fact that the defendants they have to judge are not the perpetrators of the most important tax 
evasions. Due to the screening process of the tax offenders who are prosecuted, those selected are often mere figureheads who did not conceive the fraud but simply offered assistance in its execution. Suspended sentences thus seem to the judges as the best way to regulate tax fraud: it is a means to recognize the reality of the offence in a symbolic manner, without excessively penalizing the offenders themselves.

Ultimately, the increase in French prison population (from 50,000 at the beginning of the 1990s to 67,000 in 2014) completely left out the tax evaders. Even amongst the white-collar offenders, tax dodgers are particularly able to escape imprisonment: while 5,000 white-collar offenders are behind bars in France (Les chiffres clés de l'administration pénitentiaire 2013), there are none for the sole crime of tax fraud.

The British are less lenient towards the rare tax offenders they do prosecute. This is in part because in 2003, the "Sentencing Guidelines" were introduced. Their scope was widened by the Coroners and Justice Act of 2009 (Roberts 2011). These guidelines limited the discretionary power of judges to choose sentences. Even though the sentences served seem to be of less consequence than the damage caused to society (Scott Dutcher 2005), the tax offenders regularly receive significant sentences. In England and Wales, immediate custody is prescribed in close to half of the cases (Sentencing Council, "Fraud Offences Sentencing Data" 2013). However, while the tendency since around 2005 has been, generally speaking, to aggravate punishment, recent years have been marked by a reduction in the rate of convictions leading to prison terms for tax evaders. It affected only $43 \%$ of people convicted in $2012-2013$ and $36 \%$ in $2013-2014$. The average duration of imprisonment also decreased: it went from 40 months in 2011-2012 to 15 months in 2013-2014 (Freedom of Information Request). This trend contrasts with the tendencies of indictable offences in general, for which recourse to imprisonment followed a contrary trend 
(“Criminal Justice Statistics Quarterly” 2014). Symmetrically, since their resuscitation in 2003, the proportion of suspended sentences for tax evaders has not ceased to rise; it now exceeds 20\%. In the absence of modifications to the "Sentencing Guidelines" during this period, this mitigation of the severity of judgements most likely reflects the lesser gravity of the cases prosecuted and the smaller proportion of cases related to organized fraud.

Despite such relative clemency, British courts differ from their French counterparts by the greater severity of punishment meted out for tax fraud. Indeed, on the British side, tax evaders who are not sentenced to imprisonment -specifically, between a half and two thirds of them- do not thereby avoid all effective punishment.

\section{Infamy}

In Britain, "Community Orders" are attached to about $15 \%$ of tax offenders (Sentencing Council 2013). It is the punishment recommended when the defendant has a low level of guilt (which essentially relates to a conformist attitude) and when the fraud concerns a relatively small amount ("Definitive Guideline" 2014). ${ }^{7}$ This type of sentence is also used for defendants of high social status. In May of 2014, the public relations consultant to the stars, Richard Hillgrove, was found guilty of tax fraud because of his failure to pay $£ 52,000$ in VAT and $£ 45,000$ in PAYE, and was sentenced to 15 months of imprisonment, suspended for 24 months, and to 200 hours of community service. Above all, the criminal procedure is reinforced by significant publicity that is designed to shame the tax offender. The process of "naming and shaming" does not result directly from a judicial decision, but rather from a policy of communication controlled by HM Revenue and Customs. Although tax secrecy forbids revealing the results of tax audits, the label "bad taxpayer" -and even worse, "offender"- effectively bypasses this ban. The sentences imposed on tax cheats are widely advertised, sometimes accompanied by photographs, in the 
brochures, reports and web sites of the tax administration, as in the general press. The agents of the tax administration are encouraged to cooperate with the media, for whom they prepare press releases that are "ready to go". It results in shaming not only the celebrities (such as comedian Ken Dodd or jockey Lester Piggott), as was mainly the case in the last decades (Levi 2006), but also the banal offenders such as builders, wholesalers or fast-food owners. The publicity that can accompany a prosecution is therefore, according to the agents interviewed, among the significant criteria when deciding whether or not to prosecute a taxpayer. Even when they do not result in a prison sentence, criminal prosecutions stigmatize the offender.

The situation is quite different in France. While French judges almost systematically reject imprisonment, they still rarely use other available sanctions (except for suspended sentences). An order for community service is never applied to tax offenders. This attitude may be related to the law that requires the agreement of the convicted person for such a sentence. In fact, however, the idea of resorting to this punishment seems completely incongruous to the judges interviewed. In their eyes, the reintegrative virtue of such a sentence is reserved for an unemployed and marginalized offender: this attitude is the implicit recognition that -unlike the reckless driver or welfare cheater to whom such community work is typically assigned- the tax cheat has not committed an incivility placing him beyond the social contract.

French judges systematically favour sentences that do not threaten the social integration of the tax evader. For this reason, they only very rarely pass sentences that deprive the convicted person of civic, civil or family rights (in just 5\% of the cases); and when they do, it is only for short periods ( 1 or 2 years). They also quite readily allow the conviction not to be registered in the criminal record - if the convicted person pays off his tax debt and if such an official record would prevent access to public or regulated employment. All the sanctions that might have 
imposed the stigma of criminality upon the taxpayer have been discarded. Previously, the law prescribed the systematic publication of conviction for tax fraud, but the judges would neutralize this penalty by having the notice of conviction appear in publications that no one, or nearly no one, would read. In 2010, the Sages of the Constitutional Council (Sages du Conseil Constitutionnel) ended the mandatory publication for tax offences in recent years, declaring it to be incompatible with the principle that penalties must be individualized.

This indulgent attitude on the part of French judges derives, to a certain extent, from their social proximity to these taxpayers with whom they share a concern for reputation and honour (Clinard and Yeager 1980, 286-294). Yet, this attitude cannot explain the complete picture. For numerous defendants -who are closer to "blue collars" than to "white collars"- the punishment system involves an unconscious assumption, shared by all members of the judiciary, that prevents them from seeing a tax cheater as a criminal. In France, the tough methods of inquiry (custody, interviews of witnesses, interrogation of suspects...), which can generally only be implemented only after transmission of the tax file to the prosecutor (specifically, after the conclusion of the tax audit), are very rarely used against tax offenders. In the context of scarcity, both of time and manpower, tax cases are rarely given priority. Several factors contribute to this practice. Firstly, tax cases come before the judicial institution many years after the completion of the fraud, when the taxpayer is fully aware of the charges against him and has had all the time needed to hide the evidence. Moreover, the extended procedure governing the selection of these cases has given them the appearance of "closed files": while the tax authorities, in reality, rarely outline the precise mechanisms or economic logic of the fraud, the elements that are revealed are sufficient to establish the intention of evading taxes and to obtain a conviction. In many cases, the criminal inquiry amounts to a summoning of the suspect for an interview. If the suspect 
agrees to appear, he will only have to answer a few questions that are basically aimed at producing a confession, but no further investigation will be undertaken. The meeting is not meant to further highlight the criminal side of the accused. The new legal procedure enacted in 2010 shortens delays by making it possible to initiate the criminal investigation before the end of the tax audit, but this process concerns less than $10 \%$ of the cases. Still, the tax evader is not treated as a genuine offender. He appears in court free of custody, neither is he surrounded by police officers, nor is he enclosed in a dock, as is the case in British Crown Courts. The case is processed swiftly, rarely lasting more than an hour, and involves a tribunal that is always composed of three professional magistrates who are often new to taxation. When the taxpayer is truly a white-collar worker, the time is spent persuading the judges that the accused does not have the attributes of a habitual criminal (Coleman 2005).

During the brief hearing, judges focus on technical complexities; discussion essentially relates to the mechanism of the tax fraud. The dishonesty of the taxpayer is thus left still more in the obscurity as the audience marks the beginning of a new narrative. Committed to an ideal of judicial independence, the judges favour their own views over those of the tax inspector who initiated the inquiry and who, contrary to British trial practice, is never called as a witness. Although failing to completely neutralize the evidence assembled by the tax authority, when the accused knows how to respond to the expectations of the judges by discharging his tax debt and by making amends, he can successfully shed the image of an noncompliant and arrogant taxpayer. He will thereby avoid hard penalty.

In the end, except for a few taxpayers who do not know how to conduct themselves during their hearing (XXX 2011), the only sentence that has any real significance occurs when the court declares the tax debt to be a jointly held obligation: such a characterization allows the tax 
authority to transfer the corporate tax debt to its director. It is as if the criminal procedure were to function in the same way as a purely administrative process, the only purpose being to recover unpaid taxes. The French tax authority seems to have adapted very well to this situation. It places all its hopes on the penalty of confiscation. However, seizing the tax fraudster's assets is just one method the tax authority has to effect restitution, in kind - that of which it has been deprived.

Officially, the senior French officials in charge of implementing penal policy are the same ones who promote the theme of the sentence as a deterrent: making examples of offenders serves to limit the propagation of undesirable behaviour. This argumentation is very far from what occurs in reality. If the intent were truly to intimidate all potential offenders, the exemplary punishments would have to be advertised, but they are not. Indeed, revealing the names of convicted persons would doubtlessly clash with the French conception of respect for privacy. However, the tax authority does not publicize its own more repressive actions, while preserving the anonymity of the perpetrators. While the repression of petty crime is accompanied by a strong appeal to the media to publicize the processes and operations of the police, the dramatization of the fight against tax fraud came to a halt in the parliamentary arena where major laws regarding this topic have been passed in the last five years. The penal procedure is, above all, another tool for the recovery of defrauded money. The objective of returning money to the coffers of State outweighs all other considerations.

On both sides of the Channel, the governmental discourse is the same: it condones international outrage against tax evasion by advocating the strengthening of penalties for tax evasion. This intention has been effectively realized in Great Britain (by increasing the number of prosecutions) and in France (by the slight diversification of prosecutions to act more forcefully against large-scale frauds). Nevertheless, in neither country does the penalization of 
tax fraud truly result in the tendency of "defining deviancy up", a trend that could be observed in the case of street crimes.

In both countries, the new penal policies aim to balance the social demand for state repression with the traditional abstention. On one hand, they remain committed to the belief that the economic life should have as much leeway as possible; whereas on the other, the budgetary crisis requires the prevention of revenue losses from tax evasion. In order to conciliate these two targets, both countries have chosen a practical penal strategy, one that relies on the assumption that the criminalization of tax fraud aims, above all, to increase the total tax recovery. Therefore, a calculation of the expected value of the sanction, in relation to the cost involved in the criminal procedure, leads to the prosecution of only a few taxpayers. The result of the numerous filters before prosecution may take place is often that only small-time offenders end up in court, while those who have orchestrated more complex frauds frequently escape any kind of punishment. Whilst apparently justified by the lack of resources, particularly the shortage of judiciary means, the differential administration of tax illegalities is indeed strongly linked to the nature of neoliberal penal vision (Harcourt 2012).

Despite these commonalities -the aim to make money by criminalizing and the severe selection of accused tax dodgers- the penal strategy takes on two very different shapes on either side of the Channel. In France, the objective of deterrence officially promoted is largely belied by the rarity of harsh sentences and the exceptional nature of publicity regarding criminal procedures. In fact, the quasi-administrative treatment undermines the moral function of the criminal procedures that are mainly a financial instrument for the improved restitution of stolen taxes. In Great Britain, the policy of HMRC, supported by the "Sentencing Guidelines", aims much more at obtaining exemplary convictions, even if they are against fewer offenders. This 
penal strategy assumes that the taxpayer is rational (Becker 1968) and will obey the law to avoid humiliation and/or jail inflicted on tax offenders.

Whereas, in the French case the punishment is only thought of as a tool to defend the financial interest of State. It is used, in the case of Great Britain, as a public demonstration of the state power.

\section{Funding}

This work was supported by the "Mission de Recherche Droit et Justice" in France.

\footnotetext{
NOTES

${ }^{1}$ Robert Marshall Faichney and David Richard Perrin, Blackfriars Crown Court, February 7, 2012.

${ }^{2}$ The British High Net Worth Unit focuses on the 5,800 taxpayers who have assets of more than $£ 20$ million, while the French National Directorate of Tax Audits has jurisdiction when annual taxpayer revenue is greater than $€ 770,000$ or when their net assets exceed $€ 6.9$ million; if we add to this group taxpayers of current notoriety and those who are the subject of a judicial procedure, the total number is about 150,000 people.

${ }^{3}$ Officially known as La brigade nationale de répression de la délinquance fiscale (BNRDF).

4 'Long-firm frauds', also known as 'bustouts' or 'overbuys', occur when a trading company is created for fraudulent purposes, first establishing a good credit history, then making large purchase from large firms, which they do not intend to pay, then disappear.

5 Tribunal de grande instance de Paris, $11^{\text {th }}$ Chamber, February 13, 2015.

6 Crown Court Southwark, July 1, 2014.

7 Sentencing Council, Fraud, Bribery and Money Laundering Offences, Definitive Guideline, 2014.
}

\section{REFERENCES}


Beckert, Jens. 2007. “The longue durée of Inheritance Law," European Journal of Sociology, 48: 79-120.

Becker Gary S. 1968. "Crime and Punishment: An Economic Approach,” Journal of Political Economy 76: 169-217.

Braithwaite, John. 1989. Crime, Shame and Reintegration. Cambridge: Cambridge Univ. Press.

Braithwaite, John. 2003. "What's Wrong with the Sociology of Punishment ?" Theoretical Criminology 7: 5-28

Braithwaite, Valerie. 2007. "Responsive Regulation and Taxation: Introduction," Law \& Policy 29: 3-10.

Clinard, Marshall B., and Peter C. Yeager. 1980. Corporate crime. New York: Free Press.

Chauvin, Sebastien and Nicolas Jounin. 2010. "L'externalisation des illégalités. Ethnographies des usages du travail 'temporaire' à Paris et à Chicago," In Les paradoxes de l'économie informelle. À qui profitent les règles ?, edited by Laurence Fontaine and Florence Weber, 113138. Paris: Karthala.

Chiffres clés de l'administration pénitentiaire. 2013. http://www.justice.gouv.fr/prison-etreinsertion-10036/les-chiffres-clefs-10041 (accessed at September 25, 2015).

Coleman, James William. 2005. The Criminal Elite: Understanding White-Collar Crime. New York: Macmillan.

Cook, Dee. 1989. Rich Law, Poor Law. Differential Response to Tax and Supplementary Benefit Fraud. Maidenhead: Open University Press.

Eitle, David J. 2000. "Regulatory justice: A re-examination of the influence of class position on the punishment of white-collar crime," Justice Quarterly 17: 809-839.

Foucault, Michel. 1979. Discipline and Punish. The Birth of the Prison (Surveiller et Punir; Naissance de la prison. Paris: Gallimard (first ed. 1975).

Friedrich, David O. 2009. Trusted Criminals: White Collar Crime in Contemporary Society. Belmont: Wadsworth.

Garland, David. 1990. Punishment and Modern Society: A Study in Social Theory. Clarendon Press.

Garland, David. 1997. “Governmentality' and the Problem of Crime: Foucault, criminology, sociology," Theoretical criminology 1: 173-214. 
Harcourt, Bernard E. 2012 The illusion of free markets. Cambridge: Harvard University Press.

Heber, Anita. 2009. "Networks of organised black market labour in the building trade," Trends in Organized Crime 12: 122-144.

Her Majesty's Inspectorate of Constabulary. 2013. An Inspection of Her Majesty's Revenue and Customs performance in addressing the recovery of crime from tax and duty evasion and benefit fraud. https://www.justiceinspectorates.gov.uk/hmic/publications/hmrc-proceeds-of-crime-2014$\underline{06}$ (accessed at September 15, 2015)

Klepper, Steven and Daniel Nagin. 1989. "The deterrent effect of perceived certainty and severity of punishment revisited," Criminology 27: 721-746.

Levi, Michael. 1981. The Phantom Capitalists : The Organization and Control of Long-Firm Fraud. Farnham: Ashgate.

Levi, Michael. 2006. "The media construction of financial white-collar crimes," British Journal of Criminology 46: 1037-1057.

Levi, Michael. 2010. "Serious tax fraud and noncompliance: A review of evidence on the differential impact of criminal and noncriminal proceedings," Criminology \& Public Policy 9: 493-513.

Mann, Kenneth. 1985. Defending white collar crime: A portait of attorney at work. New Haven: Yale University Press.

Mills, Charles Whright. 1963. Power, politics, and people: The collected essays of C. Wright Mills. New York: Oxford University Press.

Ministry of Justice. 2014. Criminal justice statistics quarterly March 2014. https://www.gov.uk/government/uploads/system/uploads/attachment_data/file/346639/criminaljustice-statistics-april-2013-to-march-2014.pdf (accessed at 4 September 2015)

Moynihan, Daniel Patrick. 1993. “Defining deviancy down,” The American Scholar 62: 17-30.

Murphy, Kristina. 2005. "Regulating More Effectively: The Relationship between Procedural Justice, Legitimacy, and Tax Non-compliance". Journal of Law and Society, 32 (4) : 562-589.

Murphy, Kristina. 2008. "Enforcing Tax Compliance: To Punish or Persuade ?" Economic analysis \& Policy 38: 113-135.

McBarnet, Doreen. 1991. "Whiter than white collar crime: tax, fraud insurance and the management of stigma," Britannic Journal of Sociology 42: 323-344. 
McBarnet, Doreen. 2013. "Questioning the legitimacy of compliance." In Legitimacy and compliance in criminal justice edited by Adam Crawford and Anthea Hucklesby, 71-90, London: Routledge.

Nagels, Carla. 2013. "Les grandes entreprises et les instances de lutte contre la fraude sociale : le jeu du chat et de la souris", Champ pénal, 10. https://champpenal.revues.org/8449 (accessed at October 14,2015).

National Audit Office. 2013. Confiscation orders. https://www.nao.org.uk/report/confiscationorders-2 (accessed at September 20, 2015).

Roberts, Julian V. 2011. "Sentencing Guidelines and Judicial Discretion. Evolution of the Duty of Courts to Comply in England and Wales," British Journal of Criminology 51: 997-1013.

Roth, Jeffrey A., John T. Scholz and Ann Dryden Witte (eds). 1989. Taxpayer Compliance, volume 1. An Agenda for Research. Philadelphia: University of Pennsylvania Press.

Schwartz, Richard D. and Sonya Orleans. 1967. "On Legal Sanctions," University of Chicago Law Review 34: 274-300.

Scott Dutcher, Jonathon. 2005. "Comment from the boardroom to the cellblock: the justifications for Harsher Punishment of White-Collar and Corporate Crime," Arizona State Law Journal 37: 1303-1308.

Sentencing Council. 2013. Fraud Offences Sentencing Data. https://consult.justice.gov.uk/sentencing-council/fraud-bribery-money-laundering-offencesguideline/supporting documents/Fraud\%20Statistics\%20Bulletin.pdf (accessed at September 20, 2015)

Steffensmeier, Darell and Emilie Allan. 1996. "Gender and crime: Toward a gendered theory of female offending," Annual review of sociology 22: 459-487.

Sutherland, Edwin. 1949. White collar crime. New York: Holt, Rinehart and Winston.

Voies et Moyens. 2014. Annexe au projet de loi et finances pour 2014, tome I, les recettes. http://www.performancepublique.budget.gouv.fr/sites/performance_publique/files/farandole/ressources/2014/pap/pdf/V MT1-2014.pdf (accessed at September 20, 2015).

Wacquant, Loïc 2009. Punishing the Poor: The Neoliberal Government of Social Insecurity. Durham, NC: Duke University Press. 
Figure $n^{\circ}$ 1: A range of filters before the prosecution

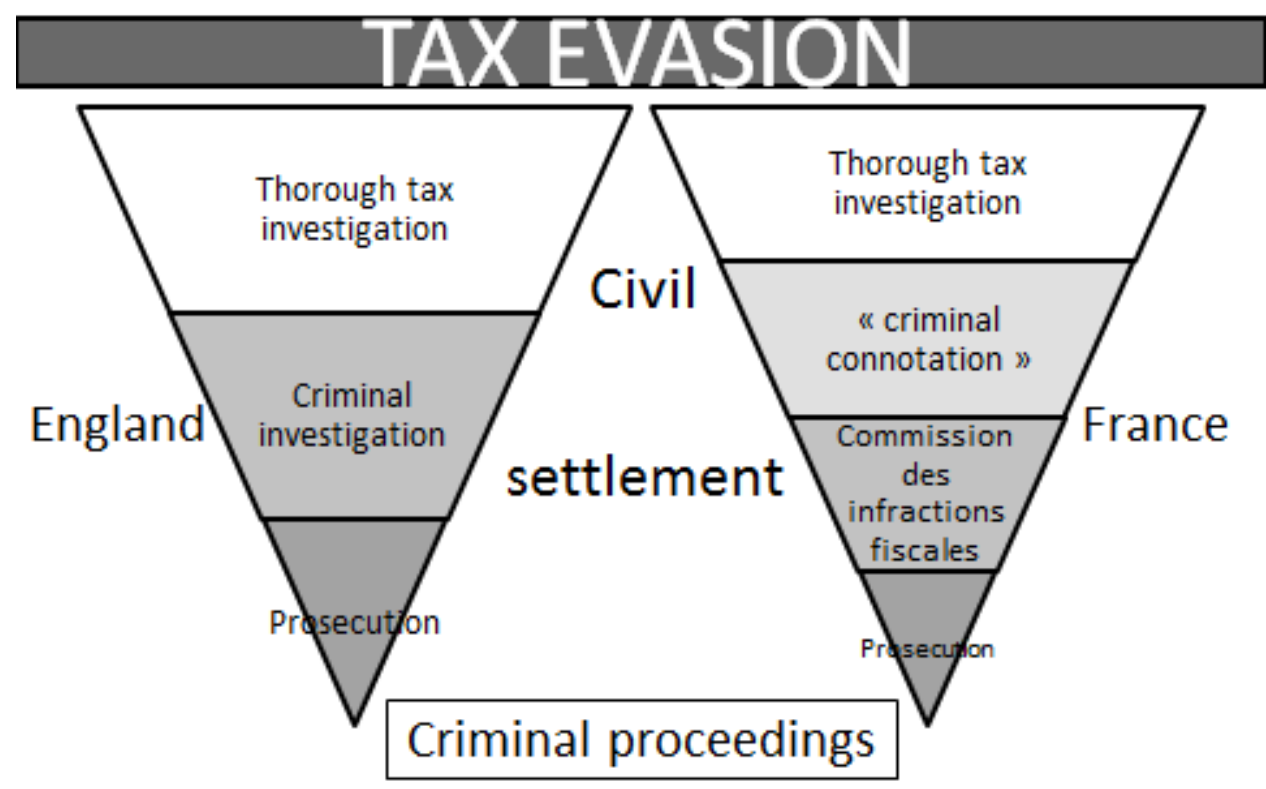

Figure n 2: A highly selective funnel 

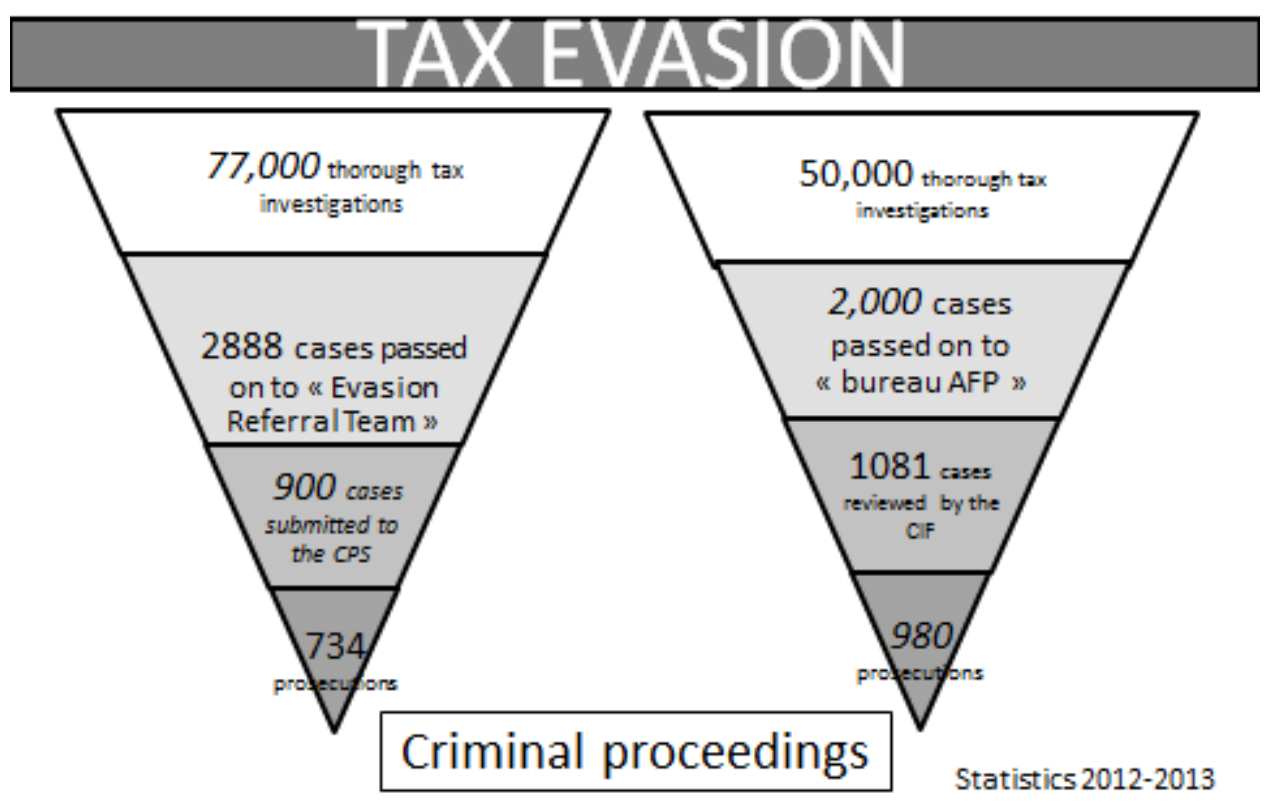